\title{
ДІАЛОГІЧНА ФОРМА СПІЛКУВАННЯ В МОВНО-ГОЛОСОВИХ ТРЕНІНГАХ ЯК СПОСІБ ФОРМУВАННЯ НАВИЧКИ ВЗАЕМОДІЯТИ
}

\begin{abstract}
Проаналізовано значення діалогічного спілкування в тренажних формах роботи над словом під час підготовки акторів драматичного театру $і$ кіно. Запропоновано варіативність застосування иьього прийому в навчальному процесі при формуванні акторських мовленнєвих навичок. Визначено основні методичні засади для практичного виконання завдань і отримання бажаного результату.

Ключові слова: навичка, діалог, тренінг, вправи, словесна дія, взаємодія, спілкування.
\end{abstract}

The importance of dialogical communication in training forms of work on the word in the preparation of actors of dramatic theater and cinema is analyzed. The variability of application of this technique in the educational process in the formation of voice acting skills is suggested. The basic methodological bases for practical implementation of tasks and obtaining the desired result are defined.

Keywords: skill, dialogue, training, exercise, verbal action, interaction, communication.

Проанализировано значение диалогического общения в тренажных формах работы над словом при подготовке актеров драматического театра и кино. Предложено вариативность применения этого приема в учебном процессе при формировании актерских речевых навыков. Определены основные методические основы для практического выполнения задач и получения желаемого результата.

Ключевые слова: навык, диалог, тренинг, упражнения, словесное действие, взаимодействие, общение.

Постановка проблеми. Розмовна мова у повсякденному спілкуванні передовсім мова діалогічна (з грецької - dialogos): розмова, бесіда, що передбачає обмін думками (а в окремих випадках - зондаж - під час переговорів) [1, 225-226]. Зважаючи на те, що слово є результатом «внутрішньої форми мови» (за В. фон Гумбольдтом), засобом творення думки (за О. Потебнею), то 3 наявних форм мовлення в театрі найпоширенішою також є діалогічна. На сцені - це двобічний словесний (мовний) ланцюг взаємодії. У процесі гри артисти завжди «повинні дбати про безпосередній процес спілкування з партнерами своїми почуттями, думками, діями, аналогічними з почуттями, думками, діями зображуваної ними ролі» $[2,269]$. Лише тоді вони стають цікавими й переконливими для глядача, захоплюють його своїм виконанням.

Насправді в театрі, як говорив режисер А. Васильєв, «все життя - в діалозі». Він буває «драматичний», «внутрішній (аутодіалог, діалогізований монолог)», «драматизований» [3, 43]. За формою може бути більше насиченим «внутрішньою дією», аніж «зовнішньою». Це, певна річ, впливає на розвиток темпоритму сцен у виставі (за К. Станіславським).

При підготовці майбутніх акторів драматичного театру і кіно у вищих мистецьких навчальних закладах опануванню особливостями та закономірностями діалогічного спілкування на сценічному майданчику значна увага приділяється під час вивчення профілюючих дисциплін «Основи майстерності актора театру і кіно» та «Сценічна мова». Тут важливо, щоб базові методичні положення обох предметів були тісно поєднані фахово.

Так, серед основних завдань вивчення «Сценічної мови» в роботі над словом $є$ :

- сформувати та розвинути здатність орфоепічно-дикційно чітко, виразно доносити думку;

- виховати навички діяти словом на партнера;

- практично засвоїти закони структурного творення й ритмічної організації семантики (послідовного розвитку) фрази для виконання наскрізної дії та реалізації надзавдання у роботі. 
3 огляду на це для тренінгових форм зі сценічної мови особливе значення має діалогічний текстовий матеріал. Він суттєво допомагає у формуванні згаданих навиків контактування з партнером, впливаючи на нього за допомогою слова, передаючи свої переживання й міркування та здійснюючи намір виконати певну дію. Інакше кажучи, діалогічність дає можливість безпосередньо відпрацьовувати варіативність мовленнєвої майстерності за законами драматичного мистецтва.

Проте застосування у вправах діалогів ще не означає наявності діалогічної форми виконання. Діалогізація в структурі обраного тексту стає «підмурівком, основою» для фантазії, дає змогу побудувати хід виконання вправи - спілкування і взаємодія «через діалог». Лише в цьому разі йтиметься про методичний прийом.

Широке запровадження такого способу роботи під час навчання видається потрібним і необхідним. Адже як у світі в цілому, так і в Україні, театральне мистецтво активно розвивається та видозмінюється. Поряд 3 класичним театром виникли різноманітні за формами театральні фестивалі, лабораторії інтерактивного театру з форматом читки п'єси, експериментальні мистецькі напрямки й проєкти (зокрема й соціальні, у форматі форум-театру): «Драма. UA», «Тиждень актуальної п'єси», «Фестиваль сучасної драми», театральний проєкт «Class Act: Схід-Захід» (створений за технологією британського театру «Treverse theatre»), «Театр переселенця/Theatre of Displaced People», «PostPlayТеатр», «Театр Сучасного Діалогу», «Театр для діалогу» (за методикою «Театр пригноблених» (ТП), заснованою бразильським режисером А. Боалем), «Українська нова драма» (театральний рух) та багато-багато іншого. Тобто «вітрила» сучасного театру наповнені «вітром саме його часу» (за Б. Брехтом). Очевидним є зв'язок театрального мистецтва 3 реальним життям, 3 подіями, що відбуваються в суспільстві. Щодо особливостей такого новаторства полемізують, дискутують театральні критики, режисери, актори й журналісти. Однак всі відзначають, що такий театр привертає увагу не лише діалогами на майданчику. Він розмаїтий і в пошуках комунікативного формату для розмови й контакту з тими, хто спостерігає за дійством. Звісно, це або стається, або ні. Щодо цього пізнавальними $є$ публікації: А. Чорноус («Театр по-новому: діалог із глядачами і реальні історії на сцені»), Ю. Голоднікової («Українська нова драма: від деструкції до створення нової естетики?»), Л. Бевзюк-Волошиної («Театр і реальність. Просторова дезорієнтація глядача») тощо.
Аналіз досліджень. Про особливість роботи над діалогом як живим спілкуванням-взаємодією і частиною суцільної дії у драматичній виставі (та про діалог 3 глядачем) значущими є думки та висновки видатних митців: Л. Курбаса, К. Станіславського, П. Саксаганського, Б. Брехта, А. Ефроса, А. Васильєва, С. Гротовського, С. Данченка, Л. Олійника, П. Брука.

Специфіка діалогізації мови в житті та в літературному творі так само була і залишається об'єктом для докладного вивчення, аналізу (М. Бубер, Л. Озадовська, Ю. Левчук, І. Баранова, I. Табінська (у медіатексті) та ін.).

Діалогічність як методичний прийом для напрацювання органічної мовленнєвої виразності застосовується і в тренінгах під час навчання. Хоча, на жаль, не так часто, як належало б. Щодо теоретично-практичних засад і способів роботи, то цікавими $є$ варіанти й творчі ідеї театральних педагогів, режисерів та акторів: Ю. Васильєва, В. Галендєєва, А. Петрової, Крістін Лінклейтер (Kristin Linklater), Г. Гладія, Є. Кирилової, О. Драча.

Формулювання цілей. Актуальність цієї статті зумовлена потребою наукового осмислення значення діалогічного спілкування в мовно-голосових тренінгових формах роботи та ролі діалогу у формуванні фахових мовленнєвих акторських навичок при навчанні. Метою публікації є: розкрити й обгрунтувати переваги використання діалогічного прийому в тренажах.

Виклад основного матеріалу. Сам по собі тренінг (англ. - training) — процес здобуття навичок завдяки отриманому досвідові після виконання комплексу вправ для тренування (від англ. to train - виховувати, навчати); набуття певної майстерності [1, 1264-1265].

Себто йдеться про цілеспрямовану, організовану і систематичну діяльність для досягнення бажаного результату. На різних етапах (семестрах) навчання конструктивні завдання в тренажах і вимоги щодо якості й точності виконання, доповнюються, стають складнішими. 3 варіантів роботи тренажні вправи можуть бути групові (колективні) та дрібногрупові. А враховуючи те, що викладання сценічної мови вимагає індивідуального підходу до кожного студента (беручи до уваги його творчі дані, індивідуальну будову мовного апарату й фізіологічні можливості), то при роботі над технікою мовлення (голос, дикція, дихання) доцільною $\epsilon$ індивідуальна робота. (Зокрема, за потреби у формуванні індивідуального комплексу тренувальних вправ для студентів зі складним мовним апаратом.) 
3 приводу гуртового виконання, то у таких вправах, окрім виховання мовленнєвого вміння, одним з головних завдань $\epsilon$ ще те, щоб результат мав характер гармонійної єдності (дій, рухів). Для актора, який грає роль у виставі, немаловажна річ вміти бути в ній частиною «художнього ансамблю» (за П. К. Саксаганським). Через те, що вистава - «це не виступ окремих “талантів”, аби здивувати глядача. Це суцільний мистецький твір» $[4,167]$. Ансамблева злагодженість у роботі — це важлива властивість фаховості.

Втім, на жаль, подеколи колективні вправи чимось нагадують масову сцену у пересічній виставі. (Не секрет, що навіть дехто з режисерів-профі не дуже любить той період, коли потрібно вибудовувати ці сцени: важко досягнути органічної правдивості).

Щодо результату виконання в групових тренажних вправах найчастіше трапляються такі помилки: хтось працює, а хтось просто формально повторює за іншими, «ховаючись за гуртом», думаючи, що його (iii) «не видно» чи «не чути помилку»; у вправах з голосу наявне форсування звуку (крик); при використанні тексту — інтонування змісту «хором»; поспіх і формальність по лінії внутрішнього процесу тощо.

Хоча у тих, хто спостерігає збоку, подеколи справляється враження, що «нібито звучать добре», «начебто вимовляють правильно» (з оцінок після показів). Певна річ, у цьому не можна «звинувачувати» лише виконавців. Хоч і їхня провина так само є. Однак у більшості таких випадках у вправі просто не чітко визначені методичні завдання: на формування й набуття якої саме акторської мовленнєвої навички ця вправа спрямована? Тобто, з одного боку, досягнути точності виконання вправи в гуртовому варіанті справді складно, а з іншого - яке завдання, такий і результат. Просте говоріння-проговорювання тексту «хором» не має чіткої мети й завдання. Кожна тренажна вправа жодною мірою не має бути «механічною муштрою», а лише з чітко окресленим колом вимог відповідно до поетапних завдань тренінгів.

Скажімо, на самому початку роботи над диханням чи голосом у гуртових практичних вправах суттєво покращує результат виконання завдань «через образ». Зокрема, порівнюючи процес добирання повітря з розпусканням квітки на «дні живота» (ділянка діафрагми); звукову хвилю 3 «корінням», що через ноги проростає в землю чи «як гілля, тягнеться» в небо через руки, маківку голови. За таким самим принципом побудова- ні вправи для опанування комбінованим (змішано-діафрагмовим) типом дихання, для активізації міжребрових дихальних м'язів та на резонування звучання - «Ниточка», «Кран», «Пружинки», «Калачик» та інші [5, 258-261]. Такий спосіб не лише безпосередньо (чи опосередковано) допомагатиме опановувати мовленнєвими навичками, а й сприятиме розвиткові творчих можливостей та уяви в студента, тим самим допомагаючи правильно дихати й звучати.

Окрім використання згаданого прийому, у тренажах надзвичайно важливо вибудовувати вправи на партнерській взаємодії, залучаючи студентів для виконання рідше колективно (чи індивідуально), а частіше по двоє, по троє-четверо. Так вони легше засвоюють матеріал і більш плідно працюють, бо точніше чують і аналізують свої (й чужі) помилки, «чіпляються» один за одного, впливають словом, дією, взаємодіють між собою. Та й «драматичний актор зрідка буває на сцені один. Лише в час коротких хвилин монологу $<\ldots>$ Вміння взаємодіяти 3 партнером - от що є головним для драматичного актора» $[6,189]$.

Багатьма вченими-науковцями (зокрема й уже згаданими В. фон Гумбольдтом, О. Потебнею) доведено, що у монологічній та діалогічній формах спілкування мовнорухові і текстотворчі процеси не однакові. В діалозі вираження думок, їх сприйняття, реакція на них темпоритмічно відбуваються інакше. А в динамічному діалогічному спілкуванні - інтенсивніша внутрішня сила звука. Це не може не позначатися на швидкості та віддиференційованості процесів артикуляторики, безпосередньо вносить корекцію в дихання (за В. М. Галендєєвим).

I як основний, і як допоміжний прийом «через діалог» - доречно буде застосовувати у тренажних вправах за всіма розділами 3 техніки мовлення дисципліни «Сценічна мова». Щодо поетапності використання та вибору текстів, то варіативність визначається семестровим завданням: для набуття якого саме досвіду та вміння. Так, спершу для складання різноманітної складності ситуативних діалогів можна взяти дикційні звукосполучення, швидкомовки, лічилки, приказки (чи загадки) тощо. Обов'язковою умовою для цих придуманих історій має бути дія. Бо «дія $\epsilon$ головний засіб реалізації способу мислення», а «діалог починає пружинити» й викликати інтерес лише тоді, «коли актор схоплює дію» $[7,19$ : 177]. Попервах це можуть бути: «діалог-суперечка», «діалог-змагання» чи «діалог-дражнилка» (скажімо, між дівчатами, між хлопцями, чи між 
і тими й тими). Далі бажано б використовувати авторські діалогічні тексти (наприклад, «Вовки» С. Руданського, «Базіка», «Допоміг» і «Настирливий» Г. Бойка) чи з усної народної творчості («Чи куриш? То й кури», «Жолудь», «Куди їдеш, Явтуше» та ін.) [5, 348-353]. Зауважимо, що в першому семестрі навчання 3 авторських творів слід обирати не занадто складний за психологічним завданням матеріал (однак досконалий за змістом і формою). В подальшій роботі, зокрема, над постановкою розмовного голосу, уже варто б застосовувати складніші діалоги (з поезії, драматургії), в «основі» яких також має бути «дія» (за А. Васильєвим).

3 досвіду: працюючи над дикцією у такий спосіб (взаємодія «через діалог»), учні точніше й легше опановують навичку чіткої вимови того чи іншого звука. Наприклад, ефективними в роботі над покращенням результату унормованого (без зайвого пом'якшення) звучання українських шиплячих є тексти (з наявністю драматургії взаємин, конфлікту, дії):

1. - Сестрице, чи ткачі тчуть, чи не чуть?

- Чуть-чуть тчуть, ледь човники волочуть, бо їсти й чуть-чуть не чуть!

- Нехай ще чуть-чуть потчуть, бо вже чуть, що перепічки печуть.

2. - Сестривечір, добрички! Чи не теличили моєї виді?

- А яка ж твоя видя?

- Під сіреньким червоненьке, на лисинці лобик, на китичці шия, на мотузці хвостик.

- Теличили, сестричко, теличили. Захвостила задерю, поочеретила геть до бігу.

За фонологічною комбінаторикою в словах для багатьох ці діалоги непрості для вимови (особливо перший). В цілому, як уже було зазначено, при напрацюванні навички правильної вимови шиплячих, (що досить складно дається), дуже корисно дикційні тексти-скоромовки самостійно поєднувати в невеличкі діалоги, працюючи через спілкування та взаємодію, використовуючи засоби мовленнєвої виразності (бачення, оцінку, ставлення). Чіткість у виконанні дії покращує чіткість вимови звука.

Не секрет, що формування навички правильної органічної вимови йотованих звуків для багатьох студентів так само $є$ непростим періодом у навчанні. Дикційною помилкою в цих звуках $\epsilon$ відсутність злитності звучання «й» 3 голосним. Особливо у місцях збігу йотованих у словах чи на межі двох слів (ї̈ яблуко, алеєю я йду тощо). Поданий далі діалогізований текст «Про кольє і монпансьє», було складено авторкою статті саме в один із таких етапів роботи. Ситуативні обставини та кількість дійових осіб дають можливість використовувати історію для дрібногрупового варіанта виконання:

- Конферансьє, чиє монпансьє і кольє у фойє ательє?

- Лавуазьє, не твоє монпансьє і кольє у фойє ательє?

- Hi, не моє монпансьє і кольє у фойє ательє!

- Готьє, не твоє монпансьє і кольє у фойє ательє?

- Нi, не моє монпансьє і кольє у фойє ательє.

- Монтеск'є, не твоє монпансьє і кольє у фойє ательє?

- Нi, не моє монпансьє і кольє у фойє ательє.

Залежно від кількості учасників, далі історію можна продовжити, звертаючись до Жусьє, Руж’є, Фур'є, Реньє. Закінчення ж є таким:

- А чиє ж монпансьє і кольє у фойє ательє?

- Я кондотьєр Ак'яб-П'єр П'ємонт Барб'є! То є моє монпансьє й кольє у фойє ательє! Адью, конферансьє, Лавуазьє, Готьє, Монтеск'є, Жусьє, Руж’є, Фур'є, Реньє! [5, 138]

У роботі, як додатковий об'єкт уваги, можна використовувати м'ячики (тенісні) чи інші предмети. Для автоматизації та диференціації правильних артикуляційних рухів у діалогічному прийомі не зайве буде, окрім помірного темпу мовлення, застосовувати ще й швидкий. Бо часто-густо в повільному (чи й помірному) - вдається правильно вимовляти в тексті йотований, а на майданчику, де інший темпоритм мовлення, більша кількість завдань - навичка не проявляється. Так стається тоді, коли вона не стала звичною, коли бракує досвіду закріплення іiї через процес динамічної взаємодії та мовлення. В роботі над дикцією це дуже суттєвий аспект. Якраз працюючи в діалозі в різних мовленнєвих темпах органічніше набуваються вміння й автоматизуються. Звісно, прискорення темпу мовлення має бути вмотивоване й виправдане характером розвитку дії та вчинків в історії.

Слушно буде зауважити про використання діалогічного прийому у вправах-етюдах 3 техніки мовлення. Оскільки інколи доводиться чути доволі категоричні думки про недоцільність такої форми роботи над словом у мовно-голосових тренажах. По-перше, за загальними завданнями і способом виконання це вправи комплексні: одночасно напрацьовуються кілька мовленнєвих навиків. Ба більше, вони поєднують в одне ціле слово, рух і акторську майстерність та зорієнтовані на розвиток моторики мовлення. Студенти здебільшого пра- 
цюють парами. Робота побудована на партнерстві, взаємодії, що вимагає зібраності й уваги. До того ж, одна річ працювати над дикцією чи постановкою дихання й голосу у статиці. Інша ж - через етюдну форму, в русі, та ще й динамічному (що, до речі, $є$ ближчим до «життя на сцені»). Комбінації рухів можуть бути як складними, так і помірно складними (залежить від фізично-фізіологічних можливостей студентів). При використанні жвавого мовлення не слід обирати занадто швидкого, аби не втрачалася орфоепічно-дикційна чіткість. Такі етюди обов'язково мусять бути невеличкою історією, побудованою за законами драматургії та сценічної дії, а не просто формальною зміною положення тіла. Зовнішні рухи народжуються від внутрішнього імпульсу, що спонукає до тієї чи іншої дії. І вибудувати вправу саме у такий спосіб, на жаль, не всім вдається. Це потребує акторсько-режисерських здібностей, знань, умінь. Хоча, звісно, такі вправи є досить непростими і щодо мовлення, і щодо фізичних рухів.

По-друге, для таких вправ не будь-який текст годиться, хоча в цілому матеріалу для цього є достатньо. Приміром, це можуть бути твори із своєрідним віршовим та фонетичним малюнками. А різнометричні (чергування коротких і довгих рядків) словесні конструкції, наявність переліку однорідних та неоднорідних понять дають можливість створити різноманітні ритмічні хвилі в процесі виконання. Це можна використати у етюдах-вправах на активізацію дихальних м'язів (зокрема міжребрових, черевного преса), на виховання навичок правильного голосоутворення під час інтенсивної фізичної дії та активного добору дихання (в динамічній дії - через рот).

Так само не слід забувати, що на сцені будьяка репліка діалогу за метою висловлення має чітке завдання (спростувати, заперечити, підтвердити, спонукати, змушувати чи схиляти до якихось вчинку, дії та ін.). Від самого початку в діалогах обов'язково потрібно чітко проаналізувати всі запропоновані обставини, розібрати сутність змісту, визначити конфлікт в основі сюжету тощо.

Для таких вправ-етюдів можна використовувати не лише віршовані, а й прозові діалоги. Чи поєднувати між собою різні. Як-от історія «Усе гаразд» (діалог пана з гуменним) з усної народної творчості, яку у віршованому варіанті під назвою «Гуменний» вдало й дотепно «переспівав» поет С. Руданський. Також у цього ж автора придатний для таких вправ текст «Переслів'я», що $є$ похідним від української народної казки-небилиці «Як ми з дідом чумакували» $[5,350,238,388]$.
А от у роботі над голосом (для вправ колективних чи парами) більшою мірою варто брати саме ритмізовані тексти - вірші (бажано $з$ наявністю широких голосних «а, е, о» та огубленого «у»). На розширення діапазону голосу, зміцнення його щодо виразної звучності використовується різноманітний за «довжиною рядка» віршовий матеріал. Особливо гекзаметричний (від грец. hexametros - шестимірник). Йдеться про шестистопний дактилохореїчний розмір. Довжина цього вірша дає можливості для варіантів будови й виконання діалогічних вправ, які за методичними завданнями також $€$ комплексними. Виконувати їх можна як у статиці (стоячи, сидячи, лежачи), так і в русі, працюючи підгрупами чи по двоє. При вихованні голосових навичок м'якого переходу звука з регістру в регістр, удосконалення звуковисотного діапазону та розвитку палітри тембрального забарвлення, в процесі роботи акцентується увага й на тому, як контролювати експіраторну енергію при звучанні голосу. Окрім цього, важливу увагу слід приділяти й дикційній чіткості звуків. I не лише голосних, а й приголосних. В цілому, як писав П. Саксаганський, «гекзаметр дисциплінує артиста, бо тут не можна переставити чи викинути не тільки слова, але й дрібного сполучника» $[4,88]$.

Основний прийом роботи у вправах на такому віршовому матеріалі - кантиленна (плавний, помірний перехід від звука до звука) розмовна та розмовно-протяжна манери звуковедення 3 використанням різних темпових і силових змін мовлення: плавний перехід - легато (від іт. legato — зв'язаний); тихе звучання - піано (від іт. piano - тихо), а динамічніше - форте (від іт. forte - сильний, динамічний). такі:

Варіанти виконання вправ зазвичай беруться

- у розмовній інтонації на кожному рядку підніматись на півтону (6-8 «тональних сходинок»), а далі - опускатись;

- у розмовно-протяжній інтонації на кожному рядку підніматись на півтону (6-8 «тональних сходинок»), а далі - опускатись;

- на окремих рядках чергувати силу звучання голосу (forte - в розмовно-протяжній, piano в розмовній і навпаки);

- хроматична гама: вимова кожного слова окремо, піднімаючись на півтона в розмовно-протяжній чи розмовній інтонаціях або чергуючи їх, змінюючи темп вимовляння кожного рядка як окремо, так і в його межах.

Також можна використовувати й три- або чотиристопний віршовий рядок (як по одному, так і по два на «одну порцію»). 
На силові, діапазонні й темпові зміни мовлення (а також на розвиток польотності звуку, фонематичного слуху, координаційної узгодженості дихально-голосових та артикуляційних рухів і дій), у роботі двома підгрупами доречно буде взяти текст-діалог (запитання-відповідь) «Гуси» В. Підпалого: «Гуси, гуси, де ви були?» — «В синім небі між хмар пливли». «Де ж те небо?» — «Впало в воду». — «А де вода?» — «Коло броду». — «А де той брід?» — «А там де й ліс». — «А де той ліс?» — «А там де й ріс». [5, 305]. Спосіб виконання: одна група ставить запитання, а друга - відповідає. Умовно ті, що запитують, перебувають у полі зору, а ті, що відповідають, - на чималій відстані. Через це сила звучання їхніх відповідей - дещо тихіша. I ті, й ті використовують прийом «на відлунювання, на удавання відстані». Голосовий посил на кшталт «а-у» за допомогою рупора із двох рук, який опосередковано допомагає точно сформувати «ротоглотковий рупор», - розвиває динамічний діапазон мовлення, пластичність звучання під час голосових «переходів-ковзань», активізує внутрішньоглоткову артикуляцію та відчуття резонансу й об'ємності звукової хвилі. Ритмомелодійний малюнок у діалозі повинен мати динамічний розвиток. Це така собі синусоїдальна звукова лінія коливання-ковзання голосу відповідно до характеру дії-прохання, від виконання якої «залежить життя». Отож дія має бути активною, наполегливою, а не млявою. Звучання голосу наприкінці, ковзаючи вниз, сходить нанівець. Звук ніби «ховається у грудний резонатор», поступово й повільно «підтягуючи хвостик», аж поки не щезне зовсім.

Зважаючи на те, що постановка розмовного голосу вимагає індивідуального підходу до кожного учня, у запропонованій вище вправі можна працювати парами, «будуючи» між собою діалог, в якому енергетичний розвиток голосового звучання має спочатку зростати вгору, а потім поступово спадати вниз. Прийом «через діалог» у цій вправі буде корисним ще й для тих студентів, які мають «здавлене» звучання голосу через перенапруження м'язів гортані та шиї.

Поміж проблематики в тренажній роботі над голосом $€$ та, що не завжди здобуті навички проявляються на репетиційному майданчику. Саме діалогізація й визначеність дійових завдань у процесі роботи допоможуть в органічний спосіб домогтися резонансного звучання голосу «на опорі» на всіх висотах діапазону, не переходячи на здавлений горловий звук чи на «форсаж», тобто на «крик».
Висновки. Підсумовуючи, слід сказати, що будь-який тренінг, насамперед, не мусить бути «дресируванням» чи «натаскуванням на результат». Проста «технічна техніка», по-перше, не має ніякого відношення до творчості, яка $є$ основою природи театру. А по-друге - у студентів виховує навичку артикуляторно-характерологічно-формального процесу мовлення як такого. А, як писав К. С. Станіславський, «нема нічого безглуздішого та шкідливішого для мистецтва як “система" заради самої “системи””.

Всі вправи в мовно-голосових тренінгах методично мусять бути комплексно зорієнтовані на формуванні профілюючих мовленнєвих (голосових, дикційних, дихальних) та емоційно-образних (бачення, оцінка, ставлення, підтекст, спілкування, міміка, жест) засобів виразності, водночас розкриваючи можливості акторської природи студента. I в цьому значною мірою допомагає саме діалогічна форма роботи: конкретика обставин дії та взаємодії в діалозі сприяє формуванню мовно-рухового імпульсу (внутрішнього поштовху, спонукання до руху мовних м'язів) і налагоджує процес дихання. Відповідно, «інтенсивність імпульсу, що виникає в корі головного мозку, відгукується в тілі єдиним процесом - зв'язком між диханням і звуком» (Kristin Linklater «Freeing the natural voice») [8, 46].

Працюючи через діалогічний прийом, студенти навчаються на майданчику мислити й виражати свої думки словом. Це, так би мовити, підготовчий етап перед роботою в драматургічному діалозі у виставі. Тобто діалогова форма роботи в тренігових мовленнєвих формах відповідає принципам роботи над словом у класі з майстерності актора, доповнює, а не суперечить їм.

\section{Джерела та література}

1. Великий тлумачний словник сучасної української мови / Уклад. і голов. ред. В. Т. Бусел. Київ ; Ірпінь : ВТФ «Перун», 2004. 1440 с. С. 225-226, 1264-1265.

2. Станіславський К. С. Робота актора над собою. Київ : Мистецтво, 1953. 671. Сс. 269.

3. Дятчук В. В., Барабан Л. І. Український тлумачний словник театральної лексики. 2-ге вид., переробл. і допов. Київ : Вид. центр «Просвіта», 2002. 151. С. 43.

4. Саксаганський П. К. Думки про театр. Київ : Мистецтво, 1955. 233 c. Cc. $167,88$.

5. Кобзар Т. В. Сценічна мова. Техніка мовлення. Черкаси : вид-во Ю. Чабаненко, 2013. 404 с. Сс. 258-261, 348-353, $138,350,238,388,305$.

6. Эфрос А. В. Продолжение театрального романа (четыре книги). Москва : Панас, 1993. Т. 3. 431 с. С. 189, 177.

7. Аристотель. Поетика / Пер. Б. Тена. Київ : Мистецтво, 1967. 134 c. С. 19.

8. Линклэйтер К. Освобождение голоса; пер. с англ. Л. В. Соловьевой. Москва : Изд-во «ГИТИС», 1993. 176 с. С.46.

9. Потебня А. А. Мысль и язык. Киев : СИНТО, 1993. 192 с. 
10. Українська мова. Енциклопедія / За ред. І. В. Муромцева. Київ : Вид-во «Майстер-клас», 2011. 400 с.

11. Галендеев В. Н. Не только о сценической речи. Монография. СПб. : СПГАТИ, 2006. 384 с.

12. Брехт Б. Театр. Пьесы. Статьи. Высказывания : в пяти томах. Москва : Искусство, 1965. Т. 5/2. 566 с.

13. Чехов М. А. Литературное наследие : в двух томах. Москва : Искусство, 1986.

14. Васильев Ю. А. Сценическая речь: восприятие - воображение - воздействие. Вариации для творчества. СПб. : СПГАТИ, 2007. 432 с.

15. Курбас Л. Філософія театру / Упоряд. М. Лабінський. Київ : вид-во Соломії Павличко «Основи», 2001. 917 с.

\section{References}

1. Busel, V. T. (2004). A great explanatory dictionary of modern Ukrainian. Kyiv; Irpin: VTF «Perun». 1440 [in Ukrainian].

2. Stanislavskyi, K. S. (1953). Actor work on himself. Kyiv: Mystetstvo. 269 [in Ukrainian].

3. Diatchuk, V. V., Baraban, L. I. (2002). Ukrainian Interpretative Dictionary of theatrical vocabulary. Kyiv: Vyd. tsentr «Prosvita». 43 [in Ukrainian].

4. Saksahanskyi, P. K. (1955). Thoughts about theater. Kyiv: Mystetstvo. 233 [in Ukrinian].
5. Kobzar, T. V. (2013). Stage language. Speech technique. Cherkasy: vyd-vo Yu. Chabanenko. 404 [in Ukrainian].

6. Efros, A. V. (1993). Continuation of theatrical novel. 432 [in Russian].

7. Aristotel. (1967). Poetics. (B. Ten). Kyiv: Mystetstvo. 134 [in Ukrainian].

8. Lynkleiter, K. (1993). Voice release. (L. V. Soloveva, Trans). Moskva: Izd-vo «HYTYS». 176 [in Russian].

9. Potebnia, A. A. (1993). Thought and language. Kyev: SYNTO. 192 [in Ukrainian].

10. Muromtseva, I. V. (2011). Ukrainian language. Encyclopedia. Kyiv: Vyd-vo «Maister klas». 400 [in Ukrainian].

11. Halendeev, V. N. (2006). Not only about stage speech. SPb.: SPHATY. 384 [in Russian].

12. Brekht, B. (1965). Plays. Articles. Statements. Moskva: Yskusstvo. 566 [in Russian].

13. Chekhov, M. A. (1986). Literary heritage in two volumes. Moskva: Iskusstvo [in Russian].

14. Vasylev, Yu. A. (2001). Stage speech: perception - imagination - impact. Variations for creativity. SPb.: SPHATY. 432 [in Russian].

15. Kurbas, L. (2001). The philosophy of theater. Kyiv: vyd-vo Solomii Pavlychko «Osnovy». 917 [in Ukrainian]. 